\title{
Investigation on health condition of a freshwater eel, Monopterus cuchia from Ailee beel, Mymensingh, Bangladesh
}

\author{
G. U. Ahmed, M. N. Akter ${ }^{1}$, S. A. Nipa and M. M. Hossain \\ Department of Aquaculture, Bangladesh Agricultural University, Mymensingh-2202, Bangladesh and ${ }^{1}$ Department of \\ Aquaculture, Hajee Mohammad Danesh Science and Technology University, Dinajpur, Bangladesh
}

\begin{abstract}
The health conditions of freshwater mud eel, Monopterus cuchia of Ailee beel, Mymensingh district was investigated through clinical and histopathological observations from September 2005 to March 2006. Monthly sampling of water quality parameters like temperature, dissolved oxygen, $\mathrm{pH}$ and total hardness were carried out. Water temperature and total hardness were at reduced level for fish during the months of November to January in the beel. Clinically weak body, rough skin, deep ulcer and grey brownish colour of the body were noticed especially from November to January. Major pathology in the skin and muscle such as loss of epidermis and dermis, necrosis of myotoms, huge vacuum spaces, marked melanomacrophage and fungal granuloma were found in December and January. Marked melanomacrophages, severe haemorrhage, vaccums, hepatic necrosis, fat droplets were found in the liver. In kidney numerous haemorrhagic areas, necrosis, few fat droplets and many fungal granulomas were seen in December and January. Histopathologically, sampled fishes were found normal in September and October and reduced pathological signs were observed in February and March. Clinically and pathologically eels were found to be more affected in December and January. Reduced temperature and total hardness might have played role in the occurrence of clinical and pathological changes in fish during the period. The fishes were affected by EUS, with the evidence of development of fungal granuloma in skin, muscle and kidney.
\end{abstract}

Keywords: Health, Freshwater eel, Disease, Ailee beel

\section{Introduction}

Among different species of eels available in Bangladesh, Monopterus cuchia is common freshwater species, which is known as mud eel. It belongs to the family synbranchidae of the order synbranchiformes. It commonly occurs in the freshwater of Bangladesh, Pakistan and throughout India (Jingran and Talwar, 1991). They often spend their daytime hiding under stones and mud or having a burrowing habit (Nasar, 1997). The gills of $M$. cuchia are reduced and the fish has a pair of air breathing organ in the form of a sac on two sides of the head. In Bangladesh, the tribal people and a few of other castes eat this fish. It is commercially important due to its high demand for export.

Freshwater eels generally available in open water resources such as rivers, haors, baors, beels, canals and floodplains with natural care. But comparatively shallow and small ponds, ditches, tanks or cisterns also can be used to culture freshwater eels which could thrive in various adverse conditions such as low oxygen levels, high temperature and shallow water.

It has been reported from the local fishermen that the population of these freshwater eels has been declining from the natural water bodies due to several reasons. The freshwater eels are recorded as rare species from floodplains and beels due to disease outbreak (Hossain and Mazid, 1995). Thus diseases have become a major problem in fish production both in culture system and wild condition in Bangladesh (Rahman and Chowdhury, 1999). Seasonal variation in water quality parameters such as total hardness, total alkalinity, $\mathrm{pH}$, temperature, dissolved oxygen and ammonia play important role for the multiplication of pathogens thus causing diseases in fishes. Common diseases of freshwater fishes of Bangladesh are tail and fin rot, bacterial gill rot, dropsy, various types of fungal diseases, protozoan diseases, parasitic diseases, nutritional disease, and various tumors (Chowdhury, 1998). In most cases, hemorrhages, septicemia, different kinds of lesions, gill damage etc. are the common pathologies of the affected fishes.

Clinical and histopathological techniques are important procedures for disease diagnosis in fishes. Several histopathological studies have been done on major carps and freshwater small indigenous fishes though only a few works have been done on freshwater eels (Ahmed et al., 2006, Ahmed et at., 2004). Considering the above, the present study was therefore undertaken to examine the health condition of mud eel through application of clinical and histopathological techniques. 


\section{Materials and Methods}

The present study was conducted for a period of seven months from September 2004 to March 2005. In this investigation Ailee beel was selected which is located at Tarakanda of Phulpur Upazilla in Mymensingh district and about $12 \mathrm{~km}$ north of Bangladesh Agricultural University campus. The average water depth of beel was $3 \mathrm{~m}$ during rainy season and in dry season it was $1.5 \mathrm{~m}$. M. cuchia were collected from the nearest fish market of the beel and studied once in a month during experimental period. Water quality parameters like temperature, $\mathrm{pH}$, dissolved oxygen and total hardness were measured at monthly intervals by using HACH's kit (Model FF-1A). Live fishes were collected and immediately carried to the Fish Disease Laboratory, Bangladesh Agricultural University, Mymensingh. The sampled fishes were observed clinically by naked eye and magnifying glass in the laboratory. Samples of fish organs, such as skin and muscle, liver and kidney were collected with the help of sharp scalpel and forceps and fixed in $10 \%$ buffered formalin for histopathological study. Then the samples were placed in an automatic tissue processor for dehydration, clearing and infiltration. The samples were then embedded at a thickness of 5 micrometers. The sections were then stained with haematoxylin and eosin stains. Then the sections were mounted with Canada balsam and covered by a cover slip. Then the slides were examined under a compound microscope (Olympus). Then photomicrographs from the stained sections were taken by using a photomicroscope (OLYMPUS, Model CHS, Japan). Pathological observation were made from the slides and photographs and compared among different months of the study period.

\section{Results and Discussion}

Water quality parameters are important considerations of health issues in fishes. All water quality parameters were within the ranges suitable for freshwater fishes, except temperature and hardness which were considerably low $\left(18^{\circ} \mathrm{C}\right.$ and $\left.40 \mathrm{mg} / \mathrm{L}\right)$ in the months of December to January. Hossain and Paul (1993) were of the opinion that the outbreak of EUS was peak when water temperature was very low, which might be due to the fact that at low temperature fish immune system ceased to function normally. So, it could be assumed that low temperature might have played an important role in increased pathology of fish organs and hence diseases. According to Tangtrongpiros (1985), a sudden drop of temperature in water was supposed to be an important predisposing cause of disease outbreak.

Fishes sampled in the months of September, October, February and March were found clinically normal. Roy (2006) observed almost similar result in Puntius sophore, Mastacembelus pancalus and Nandus nandus from beel fisheries. However, in the month of November, weak body and grayish brown colour of the skin were observed. Rough skin, scale loss was found in October and November in various small species of open water bodies (Roy, 2006). Weak body, rough skin, deep ulcer and gray brownish colour of the body were observed in December and January. However, in the present experiment clinical signs were increased in November, December and January. Akter et.al. (2006) observed rough skin, weak body and gray brownish color of the body in C. punctatus, $M$. tengra and $H$. fossilis. The authors observed different clinical signs like weak body, scale loss, dermal lesion, loss of caudal fin in November to January. Similar signs have also been reported by Barua et al. (1989-91). Ahmed and Haque (1999) mentioned that clinical signs like gray white necrotic areas were increased in December, January and February in various carp species of Bangladesh. Roy (2006) observed rough skin, scale loss in N. nandus in October and November.

In skin and muscle of $M$ cuchia, epidermis and dermis were partly lost and some vacuums were seen in dermis and myotomes were arranged normally in November (Table 1). In December and January, dermis and muscles were severely necrotic which created huge vacuums. However, marked fungal granuloma, fungal hyphae and melanomacrophage were seen during these periods (Table 1 and Fig. 3). Ahmed et al. (2007) observed total loss of epidermis and dermis, many fungal granuloma, fungal hyphae, wide empty spaces, with necrotic muscles in Thai $A$. testudineus, in December and January from two different farms. Roy (2006) observed that total loss of epidermis and dermis, severe necrosis, melanomacrophages and vacuums in skin and muscle of Puntius sophore during December to January. Gosh (2006) also mentioned that in silver carp and Thai sharputi, epidermis and dermis were lost with marked haemorrhage and necrosis in December and January and pathology of skin and muscle were reduced in February. Moniruzzaman (2000) also found almost similar results in skin and muscle of major carps in 
winter season. Akter et al. (2006) reported that loss of epidermis and dermis, necrotic muscle cells and haemorrhage were found in EUS affected $C$. punctatus, $M$. tengara and $H$. fossilis during the cold months (December and January) in Bangladesh.

In liver, huge melanomacrophage, mild haemorrhage and empty spaces were observed in November (Table 1). During the months of December and January, hepatocytes were necrotic having vacuums, haemorrhages and fat droplets (Table 1 and Fig. 4). Scott (1977) observed hypertrophy, hyperplasia, haemorrhages, necrosis in the gill, liver, spleen and kidney. Akter et al. (2006) also observed vacuoles, hepatic necrosis, fungal granuloma and pyknotic cells in liver of Channa punctatus, Heteropneustes fossilis and Mystus tengara. Internal organ like liver had highly necrotic hepatocytes, pyknotic cells, inflammatory cell during the months of December and January (Roy et al. 2006).

Table 1. Histopathology of different organs of Monopterus cuchia from Ailee beel in different months

\begin{tabular}{|c|c|c|c|c|}
\hline $\begin{array}{l}\text { Months } \\
\text { Organs }\end{array}$ & September-October & November & December-January & February- March \\
\hline $\begin{array}{l}\text { Skin and } \\
\text { muscle }\end{array}$ & $\begin{array}{l}\text { Normal, 'e' partly lost, } \\
\text { 'm' 'r' \& v' were seen }\end{array}$ & $\begin{array}{l}\text { 'e' and 'd' lost partly, } \\
\text { 'm' normal \& ' } v \text { ' in 'd' }\end{array}$ & $\begin{array}{l}\text { Severe 'n' , 'v' marked } \\
\text { 'mm', many 'fg' and 'fh' in 'd' } \\
\& \text { 'm' }\end{array}$ & $\begin{array}{l}\text { Normal structures; } \\
\text { minor few ' } v \text { ' in 'd' \& } \\
\text { 'm' }\end{array}$ \\
\hline Liver & $\begin{array}{l}\text { More or less normal; } \\
\text { few ' } v \text { ' \& 'fd' seen }\end{array}$ & $\begin{array}{l}\text { Huge 'mm', mild ' } h \text { ' } \\
\text { and ' } v \text { ' seen in 'hpt' }\end{array}$ & $\begin{array}{l}\text { Severe ' } h \text { ', 'fd', ' } n \text { ' and ' } v \text { ' } \\
\text { present }\end{array}$ & $\begin{array}{l}\text { Almost normal. Very } \\
\text { few 'v' present }\end{array}$ \\
\hline Kidney & $\begin{array}{l}\text { More or less normal } \\
\text { but ' } h \text { ', 'v' \& very few } \\
\text { 'fd' present }\end{array}$ & $\begin{array}{l}\text { 'h', 'fd', 'fg' \& ' } v \text { ' } \\
\text { were seen in 'kt' }\end{array}$ & $\begin{array}{l}\text { Severe 'h', 'n', 'v', 'fd', \& } \\
\text { numerous 'fg' present }\end{array}$ & $\begin{array}{l}\text { Almost normal only } \\
\text { 'fd' \& few 'v' present }\end{array}$ \\
\hline
\end{tabular}

$d=$ dermis, e=epidermis, $f g=f u n g a l$ granuloma, $f d=f a t$ droplet, $h=$ haemorrhage, hpt=hepatocyte, $k t=k i d n e y$ tubule, $\mathrm{m}=$ muscle, $\mathrm{mm}=$ melanomacrophage, $\mathrm{n}=$ necrosis, $\mathrm{r}=$ ruptured, $\mathrm{v}=$ =vacuoles

In case of kidney haemorrhage, few fat droplets, vaccums and fungal granuloma were seen in the month of November (Table 1 and Fig. 5). However, in December and January, marked haemorrhages and necrosis, few fat droplets, many fungal granuloma and vacuums were seen (Table 1 and Fig. 6). Occurrence of fungal granuloma in the organs indicates that fish were affected by EUS. Noga and Dykstra (1986) were of the opinion that marked granulomatus, inflammatory response were shown by fish infected with Aphanomyces sp. Hatai et al. (1994) also reported that fungal hyphae and many granulomas in the internal organs and musculature of EUS affected Colisa lalia in Japan. From the results it could be mentioned that $M$. cuchia was severely affected by disease like EUS and severe hemorrhages occurred during colder months. Among all the investigated organs, kidney and muscle were more affected compared to skin and liver. In contrary Ahmed et al. (2004) reported that external organs like skin and gill were more affected than internal organs such muscle, liver and kidneys of Channa punctatus and Nandus nandus. But in the present study skin and gill were less affected than liver and kidney which might be due to tough skin of these species.

From the clinical and histopathological point of view, most of the fishes of the beel were largely affected during the months of December and January. These results agreed with other similar works of Barua (1994) and Chinabut (1994). Low or rapidly changing water temperature, rapid or prolonged depression of $\mathrm{p}^{\mathrm{H}}$, low alkalinity and low dissolved oxygen were seasonal aggregations of fish diseases (Lilley et al. 1992). Results of the present study indicated that, apparently normal appearance was observed in September, October, February and March. Reduced level of pathological changes was found during November and severe pathological changes were recorded during December and January. So it could be mentioned that, prevalence of pathologies in freshwater fishes of Bangladesh might be related to seasonal variations of environmental factors especially to the lowering of water temperature. Johurul (2004) also made similar opinion that clinically fishes were susceptible to disease during the winter months of the year and also reported that internally kidney, liver and spleen were swollen and enlarged during the colder season. The observed diseases of the investigated fish species of Ailee beel as EUS and some pathologies such as necrosis, haemorrhages and vacuoles were prevalent. Ahmed et al. (2000 also reported that more pathological symptoms were seen towards the months of December and January, when compared with other months. The observed diseases of catfish were dactylogyrosis, gyrodactylosis, branchiomycosis, EUS and slimy diseases. 


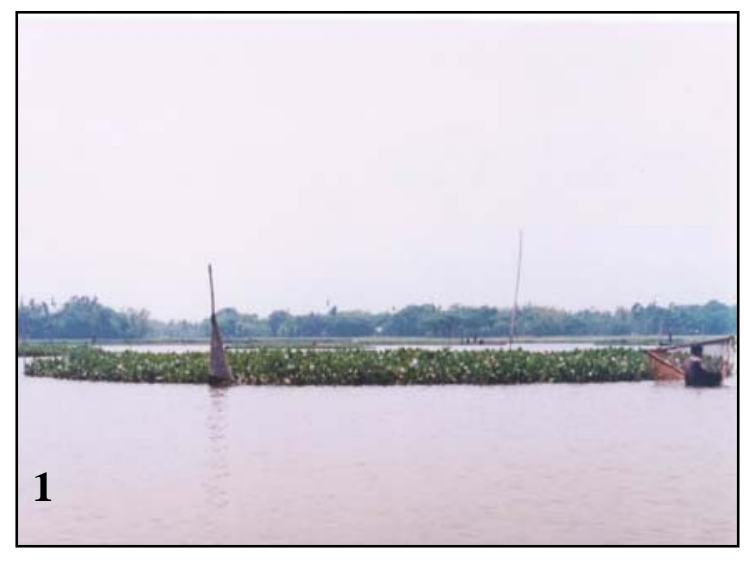

Fig. 1. Photograph of Ailee beel in September from the Northern side

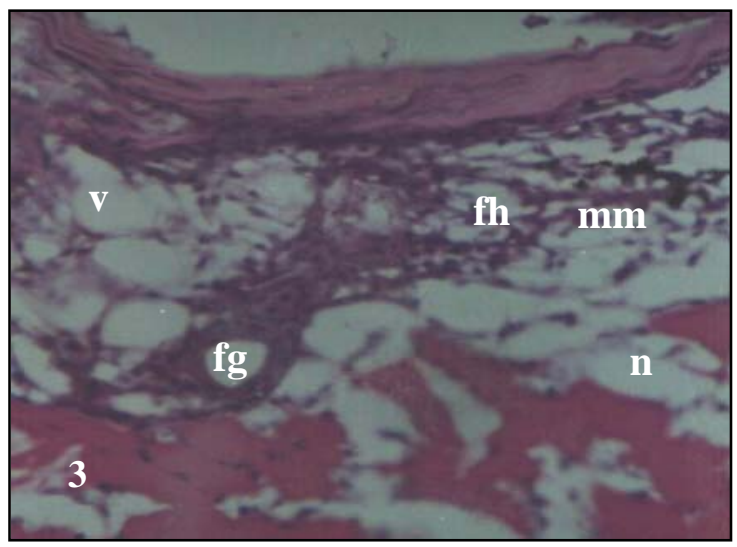

Fig. 3. Section of skin and muscle of $M$. cuchia in December \& January. Dermis and muscle were severely necrotic (n), vacuolated (v), and melanomacrophaged ( $\mathrm{mm})$. Many fungal granuloma $(\mathrm{fg})$ and fungal hyphae (fh)were also seen. $H$ \& $E$ x 430

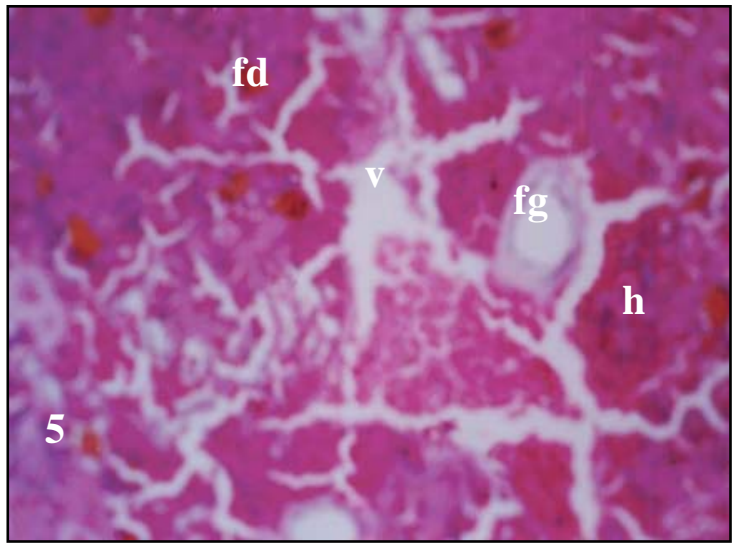

Fig. 5. Section of kidney of $M$. cuchia in November. Vacuolation (v), fungal granuloma (fg), haemorrhage (h) and fat droplets (fd) were found. $H$ \& E x 125

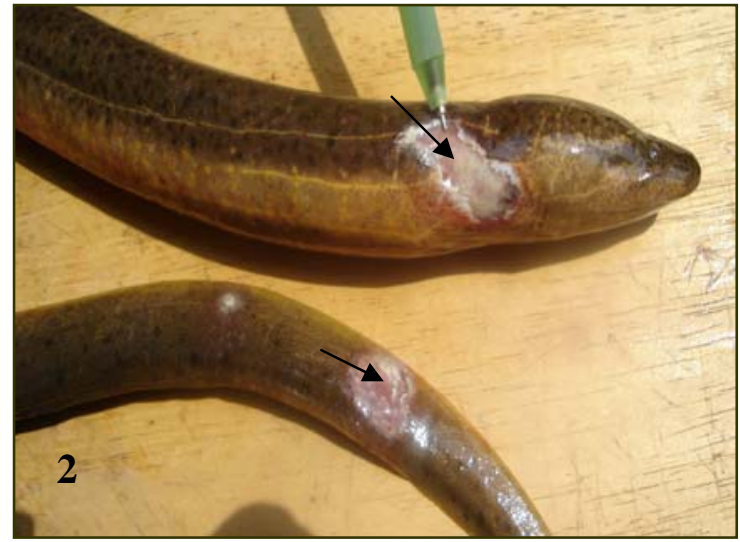

Fig. 2. Photograph of EUS affected M. cuchia in December. Arrow indicated ulcer in lateral side of head and tail region

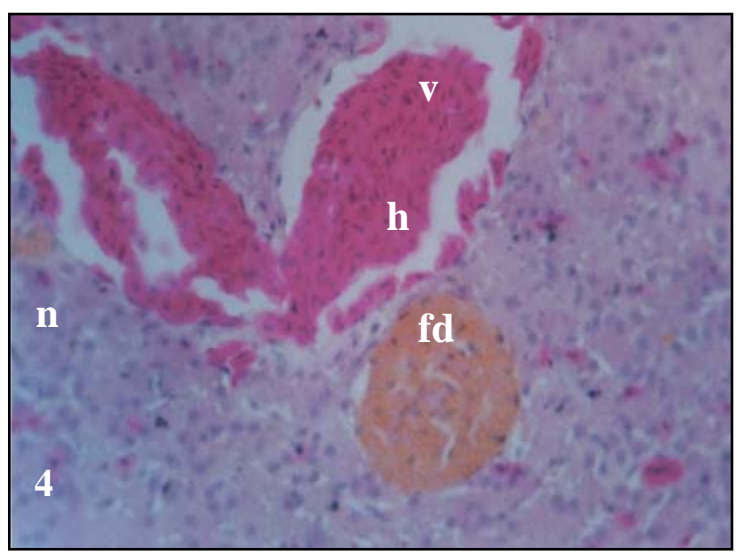

Fig. 4. Section of liver of M. cuchia in December \& January. Severe haemorrhage (h), fat droplets (fd), Necrosis (n) and vacuoles (v) were seen in hepatocyte. $H$ \& E x 125

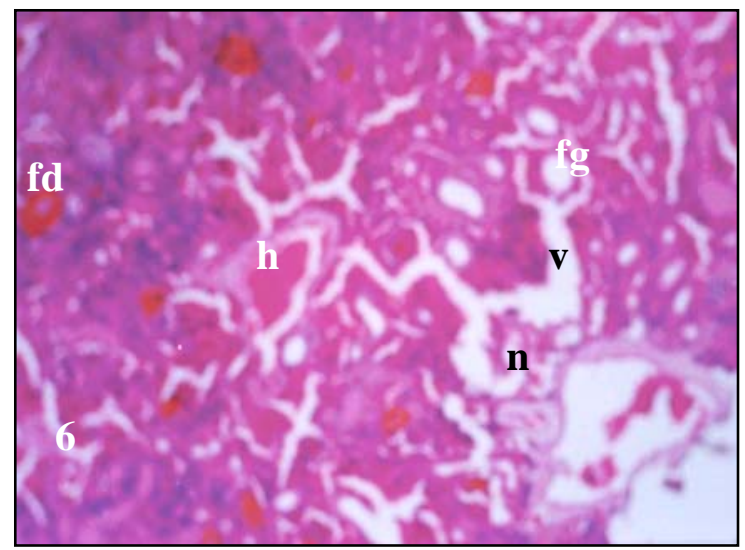

Fig. 6. Section of kidney of M. cuchia in December \& January. Haemorrhage (h), fat droplets ( $\mathrm{fd}$ ), necrosis ( $n$ ), vacuoles (v) and numerous fungal granuloma(fg) were observed. H \& E x 125 
The Ailee beel joined with many agricultural lands and in dry season its water depth was very low. As a result fishes could be stressed by different pesticides and insecticides deriving from agricultural lands. Moreover reduced water depth, temperature and hardness might be the reasons for increased infection of fishes during December and January.

In the present investigation, most of the examined eels of Ailee beel were normal and healthy from external observations. But under histopathological observations it was observed that a great percentage of fish were affected by various pathogens especially fungus. However, occurrence of disease like EUS in freshwater eels of Bangladesh could be one of the reasons for reduction of the species from natural water bodies. Thus it is necessary to take more precautionary measures to prevent and control diseases in eels to save the species. Introduction of pathogens and infected fish to the water bodies form other sources should be prevented as far as possible. Insecticides and pesticide for agriculture should not use indiscriminately which easily drains towards open water bodies and are harmful for beel fisheries. Steps should be taken to prevent the occurrence of pollution and habitats destruction of fishes especially eels. Natural feeding and breeding habitats and migration route of all fish species of open water body like beel should be protected and ensured in order to make the valuable investigated species available. However, till now very few steps have been taken to prevent and control of diseases of open water fishes. In such situation there is a need to formulate a sound management technique for open water habitat.

\section{Acknowledgment}

The authors are also grateful to Ministry of Science and Information \& Communication Technology, Government of the Peoples republic of Bangladesh for providing funds to conduct the present research.

\section{References}

Ahmed, G.U., Gosh, K., Islam, M.A. and. Tazkir-Uz-Zaman, A.K.M. 2006. Observation on health status of a juvenile exotic carp Barbodes gonionotus from different farming systems of Bangladesh. Progress. Agric., 17 (2) 185-192.

Ahmed, G.U. and Hoque, M.A., 1999. Mycotic involvement in epizootic ulcerate freshwater fishes of Bangladesh. A histopathological study. Asian Fish. Sci., Philippines, 12: 381-390.

Ahmed, G.U., Nessa, M., Hoque, M.A., Ruksana and Khatun, A., 2000. Investigation of catfish diseases in Mymensingh area through histopathological techniques. Bangladesh J. Fish., 23 (1): 45-55.

Ahmed, G.U., Parveen, R. and Sultana, S., 2004. Disease investigation of small indigenous fishes from Kailla beel in Mymensingh area. J. Bangladesh Agril. Univ., 2 (2):305-311.

Ahmed, G.U., Dhar, M., Khan, M.N.A. and Choi, J.S. 2007. Investigation of diseases of Thai Koi, Anabas testudineus (BLOCH) from farming conditions in winter. Korean J. life Sci., 17(10):1309-1314.

Akter, S., Ahmed, G.U., Roy, M.K. and Akter, N., 2006. Investigation of some small indigenous fish species from Ailee beel, Mymensingh. Progress. Agric., 17(1): 219-225.

Barua, G. 1994. The status of epizootic ulcerative syndrome of fish of Bangladesh. ODA Regional seminar on epizootic ulcerative syndrome at Aquatic Animal Health Research Institute, Bangkok, Thailand, $25-27$ January 1995, pp 13-20.

Barua, G., Banu, A.N.H. and. Khan, M.H. 1989-91. An investigation into the prevalence of fish disease in Bangladesh during 19881989. Bangladesh J. Aquacult., 11-13: 27-29.

Chakma, A.P. 2002. Histopathological observation on the effect of potassium permanganate in curing diseased small indigenous fishes. M.S. Thesis, Department of Aquaculture, Bangladesh Agricultural University, Mymensingh, Bangladesh. 60 pp.

Chinabut, S. 1994. EUS in Thailand. ODA regional seminar on epizootic ulcerative syndrome at Aquatic Animal Health Research institute, Bangkok, Thailand, January 1994. pp. 58-60.

Chowdhury, M.B.R. 1998. Involvement of aeromonad and pseudomonads in diseases of farmed fish in Bangladesh. Fish Pathol., 33 :247-254.

FRI. 1993. A manual on ulcerative fish disease in Bangladesh. Extension material series No. 4. Fisheries Research Institute, Mymensingh (In Bangladesh). 16 pp.

Gosh, K. 2006. Investigation of health status of juvenile exotic carps from various farming conditions. M.S. Thesis. Department of Aquaculture, Bangladesh Agricultural University, Mymensingh, 94 pp.

Hatai, K., Nakamura, K., Yuasa, K. and Wada, S. 1994. Aphanomyces infection in Dwarf Gourami (Colisa lalia). Fish Pathol., 29: 9599. 
Hossian, M. S. and Mazid, M. A. 1995. A manual on development of floodplain fisheries. Fisheries Research Institute, Mymensingh. PP. 2 (In Bengali).

Hossain, M. S. and Paul, S. K. 1993. Study of fish disease into the floodplains. In research progress report (June-September 1993). Fisheries Research Institute, Third Fisheries Project, Santahar, Bogra, October 1993. pp. 46 - 52.

Islam, M.J. 1999. Investigation into carp diseases through histopathological observations. M.S. Thesis, Department of Aquaculture, Bangladesh Agricultural University, Mymensingh. 79 pp.

Jhingran, A.G. and Talwar, P.K. 1991. Inland fisheries of India and adjacent countries. Vol.1 Oxford and IBH publishing Co. Pvt. Calcutta. 514 pp.

Johurul, M. I. 2004. Status of disease and health management practices of Pangasius hypophthalmus. M.S. Thesis, Department of Aquaculture, Bangladesh Agricultural University, Mymensingh. 68 pp.

Kumar, D., Dey, R.K. and Sinha, A. 1991. Outbreak of epizootic ulcerative syndrome of fish in India. pp. 345-365, in V. R. P Sinha and H. D Sriva (ed), Aquaculture Productivity Lever Research Foundation.

Lilley, J.H., Phillips, M.J. and Tonguthai, K. 1992. A review of epizootic ulcerative syndrome in Asia, Publ. Aquatic Animal Health Research Institute and Network of Aquaculture Centres in Asia Pacific. Bangkok, Thailand. 73 pp.

Moniruzzam, M. 2000. Investigation on disease of some small indigenous freshwater fishes of Bangladesh. M.S. Thesis, Department of Aquaculture, Bangladesh Agricultural University, Mymensingh. $80 \mathrm{pp}$.

Monowara, M. 2003. Monogenean infestation on certain small indigenous fishes of Mymensingh. M.S. Thesis, Department of Aquaculture, Bangladesh Agricultural University, Mymensingh. 144 pp.

Nasar, S.S.T. 1997. Backyard eel culture: International Institute of Rural Reconstruction, Silag, Cavity, Philippines. 88 pp.

Noga, E.J. and Dykstra, M.J. 1986. Oomycetes fungi associated with ulcerative mycosis in menhaden, Brevoortia tyrannus (Loatrobe). J. Fish Dis., 9: 47-53.

Parveen, R. 2001. Disease investigation of three small indigenous fishes from beels of Mymensingh. M.S. Thesis, Department of Aquaculture, Bangladesh Agricultural University, Mymensingh. 77 pp.

Rahman, M.M. and Chowdhury, M.B.R. 1999. Isolation of bacterial pathogen causing on ulcer disease in farmed carp fishes of Mymensingh. Bangladesh. J. Fish., 19: 103-110.

Ram, R.N. and Singh S.K. 1988. Carbofuran induced histopathological and biochemical changes in liver of the teleost fish, Channa punctatus (Bloch). Ecotoxicol. Environ. Safety, 16 (3): 194 -201.

Roy, M.K., Ahmed, G.U., Akter, S. and Akter, N. 2006. Study of health condition of small indigenous freshwater fishes of Ailee beel Mymensingh. Progress. Agric., 17(1): 201-209.

Salim, A. 2002. Studies on fish diseases of carp poly culture systems through histopathological technique. M.S. Thesis, Department of Aquaculture, Bangladesh Agricultural University, Mymensingh. $70 \mathrm{pp}$.

Scott, A.L., 1977. The hematological and histological effects of prolonged sublethal hypoxic stress on channel catfish Ictalurus punctatus (Rafinesque). M.S Thesis, Auburn University, Auburn, Alabama. 70 pp.

Tangtrongpiros, J. 1985. The Situation of freshwater fish disease epidemic and sanitary in Thailand. Paper presented at the 14th Conference of the 0. 1. E. Regional Commission for Asia, the Far East and Oceania. Colombo, 29 July - 2 August 1985. 